\title{
A Critical Review of the Guyana EIA Process for the Emerging Oil and Gas Sector
}

\author{
Paulette Bynoe ${ }^{1^{*}}$ and Denise Simmons ${ }^{2}$ \\ ${ }^{1}$ Senior Lecturer and the Interim Deputy Dean of the School of Graduate Studies and Research of the \\ University of Guyana, Guyana \\ ${ }^{2}$ Lecturer and Former Assistant Dean of the Faculty of Earth and Environmental Sciences of the \\ University of Guyana, Guyana
}

\begin{abstract}
In Guyana, the environmental impact assessment process (EIA) is a legal requirement of the Environmental Protection (EP) Act of 1996 (amended in 2000). In May 2015, ExxonMobil announced its first significant oil discovery approximately 190 kilometres offshore Guyana in the Liza-1 well. This initial announcement was followed by subsequent discoveries. In accordance with the EP Act, ExxonMobil's affiliate in Guyana, Esso Exploration and Production Guyana Limited (EEPGL) submitted an application for environmental authorisation to the Guyana Environmental Protection Agency (EPA) in July 2016 in order to develop the Liza field into production. With the issuance of the environmental authorisation, EEPGL became the first company to begin producing oil in Guyana in December 2019 from the Liza Phase 1 development. This paper assesses the preparedness of the EIA process in Guyana for the emerging oil and gas sector. To this end, the authors applied two principal research methods: desk review of documents, including the EP Act and World Bank Group's guidelines for offshore oil and gas developments; and semi-structured interviews with twenty-four (24) key informants representing oil companies, regulators, nongovernmental environmental organisations, civil society, and EIA Consultants. With the use of the two methods the authors assigned scores of 0 (Not at all prepared), 1 (Preparation in Embryonic stage), 2 (Partially prepared), or 3 (Fully prepared and ready) to each of the twelve (12) criteria to make a determination of the level of preparedness at the aggregate level. Eight (8) of the 12 criteria were rated 2, while the other four (4) were assigned a value of 1 . The latter were the criteria related to policy for the development of oil and gas; institutional collaboration; baseline data; and use of quantitative tools. At the aggregate level, the study identified that the Guyana EIA process was "partially prepared" for the emerging oil and gas sector. Thus, the study provides recommendations.
\end{abstract}

\section{Keywords}

Guyana, EIA process, Oil and gas, Preparedness

\section{Introduction}

\section{The role of the oil sector in an economy}

Oil accounts for approximately $31 \%$ of the energy consumption in the world [1] and "over $15 \%$ of total exports, and $25 \%$ of GDP in Russia, Central Asia and members of the Organisation of the Petroleum Exporting Countries (OPEC)" (Mitchel et al., p. 17) [2]. On the other hand, the International Energy Agency indicated that oil accounted for $39.9 \%$ of the world energy mix, while gas accounted for $15.1 \%$ in 2015 . Even though there has been a notable decrease in natural gas and oil in the global energy mix in 2018, these resources are unlikely to be replaced in the near future [3]

The oil and gas sector has strategic importance to the economic development of a country that is endowed with the natural resource, given that it accounts for a disproportionately large percentage of a country's foreign exchange earnings and incomes, its physical infrastructure and human capital in the form of highly skilled manpower; for example, Kemal [4] contends that rents from oil and gas can contribute as much as $70 \%$ of a country's GDP. Additionally, the oil and gas sector creates livelihood opportunities from economic activities such as banking, hotel and restaurant services, road construction, telecommunication and health care services, among others, for both men and women [5], especially when one considers the backward linkages with the rest of the

*Corresponding author: Paulette Bynoe, Senior Lecturer and the Interim Deputy Dean of the School of Graduate Studies and Research of the University of Guyana, Guyana

Accepted: June 09, 2021

Published online: June 11, 2021

Citation: Bynoe P, Simmons D, (2021) A Critical Review of the Guyana EIA Process for the Emerging Oil and Gas Sector. Adv Environ Stud 5(1):416-436 
Citation: Bynoe P, Simmons D, (2021) A Critical Review of the Guyana EIA Process for the Emerging Oil and Gas Sector. Adv Environ Stud $5(1): 416-436$

Table 1: Summary of impacts of offshore oil and gas sector.

\begin{tabular}{|c|c|c|c|c|c|}
\hline \multirow{6}{*}{$\begin{array}{l}\text { Impacts and } \\
\text { Environmental } \\
\text { Components }\end{array}$} & \multicolumn{5}{|c|}{ Phases } \\
\hline & \multicolumn{4}{|c|}{ Exploration } & $\begin{array}{l}\text { Development and } \\
\text { production }\end{array}$ \\
\hline & \multicolumn{5}{|c|}{ Activities } \\
\hline & \multicolumn{2}{|l|}{ Seismic survey } & \multicolumn{2}{|l|}{ Drilling and Appraisal } & Process and storage \\
\hline & \multicolumn{5}{|c|}{ Sources } \\
\hline & $\begin{array}{l}\text { Seismic } \\
\text { equipment }\end{array}$ & $\begin{array}{l}\text { Vessel } \\
\text { operations }\end{array}$ & $\begin{array}{l}\text { Operations, including } \\
\text { vessel and helicopter } \\
\text { movements }\end{array}$ & Decommissioning & $\begin{array}{l}\text { Operations, including } \\
\text { increased vessel and } \\
\text { helicopter movements }\end{array}$ \\
\hline \multicolumn{6}{|l|}{ Aquatic } \\
\hline Generation of noise & V & & $\mathrm{v}$ & & \\
\hline Generation of light & v & & V & & \\
\hline Changes in water quality & & v & v & & V \\
\hline $\begin{array}{l}\text { Changes in the dimensions } \\
\text { of the seabed }\end{array}$ & & & v & v & \\
\hline \multicolumn{6}{|l|}{ Atmospheric } \\
\hline $\begin{array}{l}\text { Changes in ambient air } \\
\text { quality }\end{array}$ & & v & v & & v \\
\hline Generation of noise & & & v & & V \\
\hline Generation of light & & & v & & v \\
\hline \multicolumn{6}{|l|}{ Terrestrial } \\
\hline Changes to soil quality & & v & v & & v \\
\hline Solid waste generation & & v & v & v & v \\
\hline \multicolumn{6}{|l|}{ Biological } \\
\hline $\begin{array}{l}\text { Disturbance to marine } \\
\text { organisms }^{\mathrm{a}}\end{array}$ & V & & V & v & V \\
\hline \multicolumn{6}{|l|}{ Social } \\
\hline $\begin{array}{l}\text { Lack of/limited access to } \\
\text { natural capital by other } \\
\text { resource users (e.g. } \\
\text { fisherfolk) }\end{array}$ & & v & v & & v \\
\hline $\begin{array}{l}\text { Changes in local } \\
\text { population levels as a } \\
\text { result of immigration } \\
\text { (labour force) }\end{array}$ & v & v & v & v & v \\
\hline $\begin{array}{l}\text { Changes in the socio- } \\
\text { economic systems due } \\
\text { to new employment } \\
\text { opportunities, inflation, } \\
\text { income differentiation }\end{array}$ & v & v & $\mathrm{v}$ & v & v \\
\hline $\begin{array}{l}\text { Changes in socio-cultural } \\
\text { systems, such as social } \\
\text { structure, practices and } \\
\text { beliefs and value systems }\end{array}$ & v & v & v & v & V \\
\hline
\end{tabular}

Compiled using information from E\&P Forum/UNEP [11] and World Bank Group [12].

economy during the planning, construction and operational phases. Importantly, these prospects of the oil and gas sector can only be realised if the local content policy, including pro-
aSome of the reported impacts on the marine biological environment include the disruption of behaviour of marine mammals due to noise, the effect of light on the diel vertical migration of phytoplankton, and damage to benthic organisms from the setting of anchors on the seabed [10]. 
curement, is favourable [6] and implemented.

\section{Literature Review of Environmental and Social Impacts of the Oil and Gas Sector}

Despite the important current and potential economic contributions of the oil and gas sector to a country, one should not ignore the negative socio-ecological impacts associated with exploration and production activities [7]. Unarguably, these impacts could occur not only during the routine phases of exploration, production and decommissioning, but during emergencies, such as spills, oil or gas well blow out, explosions, fires, unplanned shutdown events, and natural hazards. Among these impacts are: atmospheric, aquatic and terrestrial contamination; solid and liquid waste generation; noise generation (including underwater); and light generation (including underwater). Additionally, the biological (especially, marine ecosystems) and social environments could also be subject to adverse effects of the sector's activities [8-12].

A careful analysis of some of the causes of environmental impacts of gas flaring instance (Orubu (1999), has shown negative effects on the immediate environment; particularly on plant growth and wildlife, as well as on human health. The greenhouse gases such as methane and carbon dioxide emitted from gas flaring contribute towards global warming, which, if not checked, could accelerate the problem of climate change on Earth (Isah, p.33) [13].

Table 1 summarises the key adverse environmental and social impacts of the offshore oil and gas sector, with specific reference to the exploration and production phases and their associated activities. As can be gleaned from the table, the well drilling and appraisal, and the process \& storage activities of the exploration, and the development and production phases, respectively, have the greatest number of impacts. It is not worthy that three potential impacts are common to each stated phase of an offshore oil and gas project, namely: Changes in local population levels as a result of immigration (labour force); changes in the socio-economic systems due to new employment opportunities, inflation, income differentiation; and changes in socio-cultural systems, such as social structure, practices and beliefs and value systems. Further, decommissioning can result in sediment and water contamination, and damage to benthic and pelagic biodiversity $[10,11]$. A more detailed explanation of the impacts can be found in Appendix 1.

Importantly, the size and complexity of an oil and gas project, and the nature and sensitivity of the surrounding environment will determine the significance of these impacts. Therefore, not withstanding this fact, nor the global and beneficial role of the oil and gas sector, it is necessary and a very prudent policy to implement effective environmental management techniques to mitigate the adverse impacts of

${ }^{b}$ The core aim of the Paris Agreement, which came into force in November 2016 is "to strengthen the global response to the threat of climate change" by "holding the increase in global average temperature to well below $2{ }^{\circ} \mathrm{C}$ above pre-industrial levels and to pursue efforts to limit the temperature increase to $1.5^{\circ} \mathrm{C}$ above preindustrial levels." the sector in light of the growing concerns about climate and ocean change [10], acid rain and unprecedented loss of biodiversity.

In addition to the environmental impacts described above, there is an indisputable relationship between fossil fuels and existential climate change. According to Blanco, et al. combustion of fossil fuels such as coal, oil and natural gas has resulted in anthropogenic climate change, accounting for 69 percent of greenhouse gas emissions in 2010. Moreover, Parties of the United Nations Framework Convention on Climate Change (UNFCCC) and the Paris Agreement (PA) have a common objective of holding global average temperature to well below $2{ }^{\circ} \mathrm{C}$ above pre-industrial levels, and pursuing efforts to limit the temperature increase to $1.5^{\circ} \mathrm{C}$ above pre-industrial levels, to avoid irreversible climate breakdown. The Emissions Gap Report (2019) unequivocally states that global temperatures are on track to rise as much as $3.2{ }^{\circ} \mathrm{C}$ by the end of the century and that greenhouse gas emissions should have begun falling by 7.6 per cent each year starting in 2020 , if the world is to meet the $1.5^{\circ} \mathrm{C}$ maximum target called for in the Paris Agreement ${ }^{b}$.

Moreover, the recent call for Parties to raise their mitigation ambition necessitates that all oil producing countries develop, implement and enforce the requisite legislative and policy measures (for example, setting targets to ensure companies reduce carbon intensity of their offshore products and investing in carbon capture technologies), coupled with innovation and technology, to reduce the climate impact of greenhouse gas emissions. Indeed, solutions will require a tremendous amount of ambition, participation, and collaboration across society, including governments, international organizations, civil society, and the general public [14]. On the other hand, poorer countries need to be given additional time and flexibility to reduce their energy poverty and achieve SDG \# 7 (https://sdgs.un.org/goals). It is argued that these countries' contribution to climate change in the past has been minimal. Moreover, the known reserves and projected demand rates in these countries will not have a large impact on the global carbon budget (Ibid, p.7).

\section{EIA as a Precautionary Measure to Mitigate Environmental and Social Impacts, with Specific Reference to the Oil and Gas Sector}

Environmental Impact Assessment (EIA) is an effective environmental management tool that is used widely for reducing the adverse environmental consequences of development activities and promoting sustainable development $[15,16]$. Essentially, the EIA involves identifying, predicting, evaluating and mitigating the environmental and social impacts of a proposed development project prior to planning permission or regulatory decisions being granted or made $[10,15,17,18]$.

International Seabed Authority consists of all parties to the 1982 United Nations Convention on the Law of the Sea (UNCLOS) and is mandated to organise and control all mineral-related activities in the international seabed area, that is, areas beyond national jurisdiction ("the Area"). 


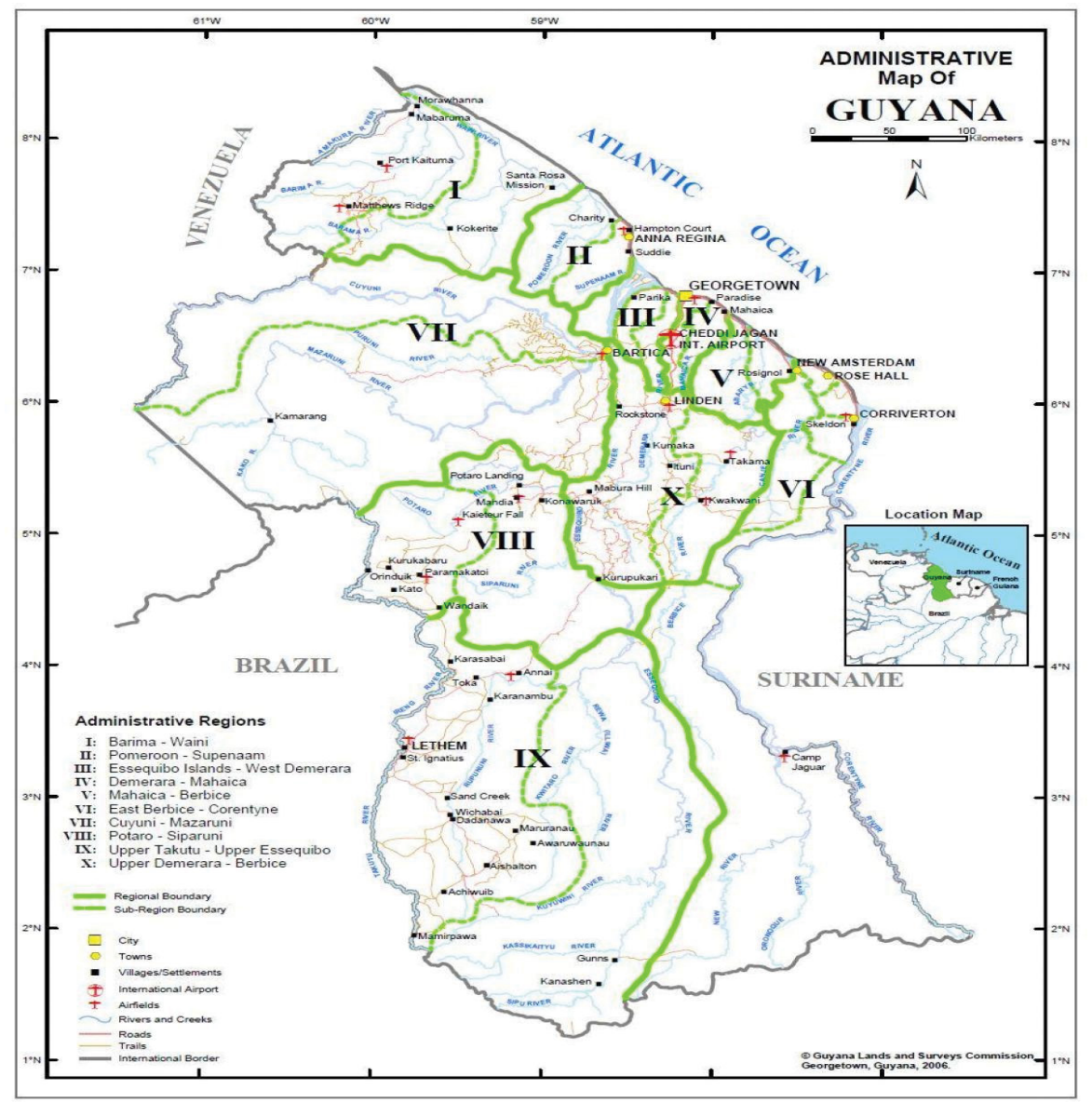

Figure 1: Guyana lands and surveys commission.

Source: Author.

The role of EIA in decision making has been formally recognised in Principle 17 of the 1992 Rio Declaration on Environment and Development which states that "environmental impact assessment, as a national instrument, shall be undertaken for proposed activities that are likely to have a significant adverse impact on the environment and are subject to a decision of a competent national authority" (United Nations General Assembly, p. 4) [19]. Additionally, Principle 15 of the Rio Declaration clearly states that:

In order to protect the environment, the precautionary approach shall be widely applied by States according to their capabilities. Where there are threats of serious or irreversible damage, lack of full scientific certainty shall not be used as a reason for postponing cost-effective measures to prevent environmental degradation. (United Nations General Assembly, p. 4) [19].

Therefore, EIA as a precautionary approach emphasises prevention $[17,20]$ and dictates preparing for the potential environmental and social impacts of developmental projects, especially oil and gas [20], even when there is scientific uncertainty regarding the possible adverse impacts of the project. Durden, et al. [21] have posited that EIA is an important tool

dSource: https://www.worldometers.info/world-population/ guyana-population/ for the International Seabed Authority (ISA) ${ }^{c}$ and its member states to operationalise several of their key obligations, including applying the precautionary approach, and ensuring effective protection of the marine environment. Further, Budd [22] and Salter and Ford [23] have advocated EIA application to the oil and gas sector, with the view to enhancing scientific understanding of environmental consequences, appreciating alternative options and scenarios, as well as the utility of stakeholder awareness and participation that are vital to environmental accountability.

The afore-mentioned statements may be justified by the fact that during the EIA process, mitigation measures, particularly those to avoid and reduce the impacts of projects, are established, and may become conditions under which the implementation of the project could proceed. Consequently, this aspect of the EIA process is particularly important in proactively avoiding the occurrence of serious adverse impacts during project implementation [10]. Additionally, mitigation measures for current oil and gas projects are recommended to follow the mitigation hierarchy of avoid, minimise, compensate/offset $[10,12]$. Moreover, during project implementation when environmental monitoring is conducted to evaluate the EIA predictions and the effectiveness of mitigation measures being used, unanticipated impacts, accidental releases, as well as impacts anticipated from normal operations 
are detected [10].

In this article, we present a review of the Guyana EIA Process for the Emerging Oil and Gas Sector. Our primary objective is to assess the level of preparedness/readiness of the EIA system for addressing environmental and social issues associated with the emerging oil and gas sector in Guyana. In order to achieve this objective, a case study of Esso Exploration and Production Guyana Limited (EEPGL), which is an affiliate of ExxonMobil, has been used.

\section{Guyana- A Brief Description}

The Co-operative Republic of Guyana, is a low-lying State with an area of $215,000 \mathrm{~km}^{2}$ (land: $196,850 \mathrm{sq}$. km water: $18,120 \mathrm{sq} . \mathrm{km}$ ) that lies between $1^{\circ}$ and $9^{\circ}$ north latitude and $57^{\circ}$ and $61^{\circ}$ degrees west longitude, and along the north-eastern coast of South America (See Figure 1). The population of Guyana in 2019 was 789, 807 inhabitants ${ }^{d}$, indicating an increase of 5.13 per cent since 2002 when the population was
751,223 people according to the Bureau of Statistics Guyana (2014). Guyana's HDI value of 0.670 in 2018 implies that the country is in the medium human development category, positioning it at 123 out of 189 countries and territories (United Nations Development Programme) [24]. The Guyana economy is traditionally based on agricultural production (mainly sugar and rice) and extractive industries (such as logging and gold and bauxite mining); however, with the recent discoveries of large petroleum deposits within the seabed of our ocean waters, new expanding opportunities in the extractive and productive industries have merged.

\section{Prospects of the Oil and Gas Sector in Guyana}

Guyana became an oil producing country in December 2019 pursuant of the Liza Phase 1 development, which yielded the first million barrels (of oil) for exportation. Consequently, the oil sector is expected to have significant impact on the country's economic outlook within the next decade.

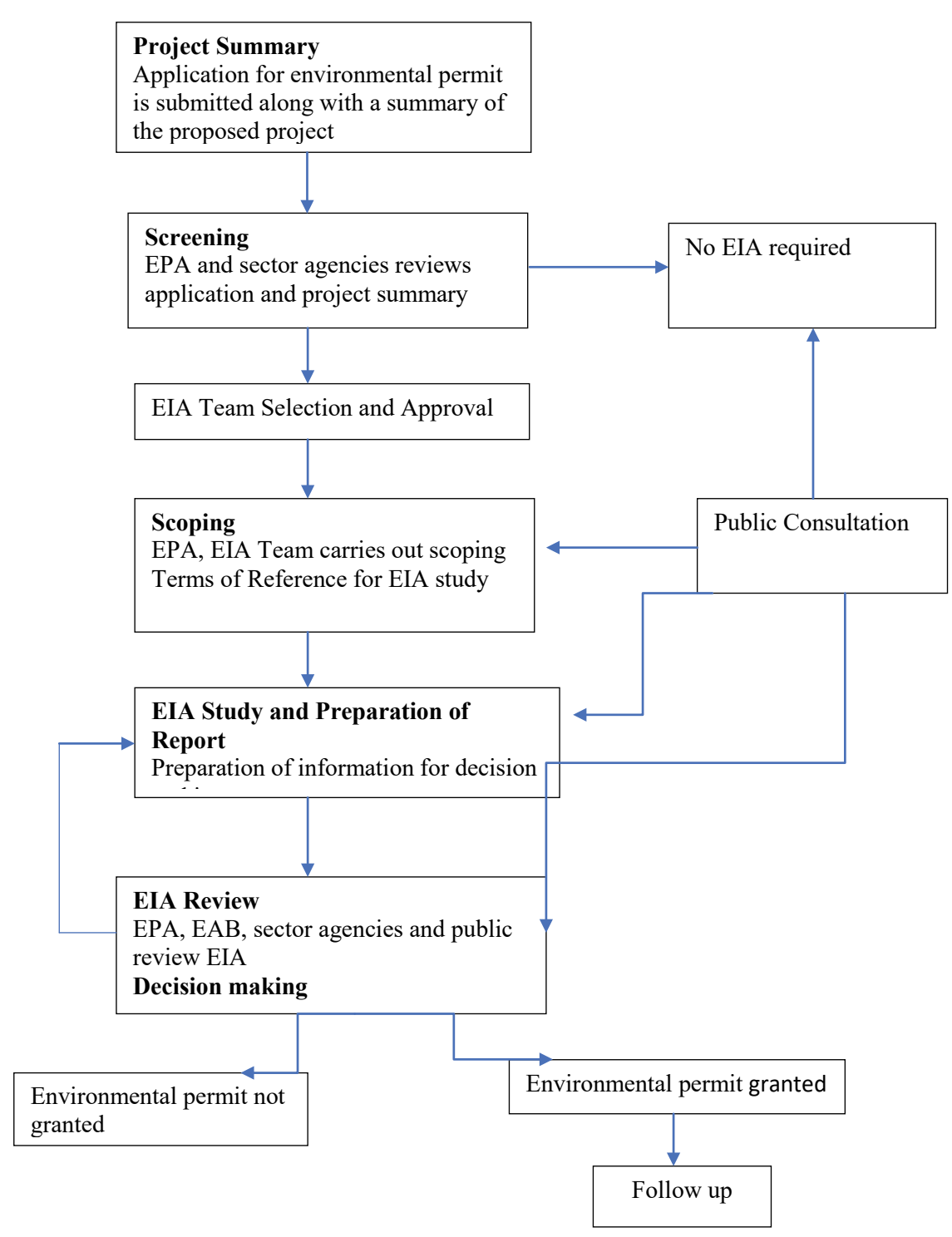

Figure 2: Stages of the EIA process in Guyana.

Source: Author. 
From a growth rate of $4.7 \%$ in 2019 , Guyana's economy is projected to grow by $85.6 \%$ in 2020 and, by 2024, the GDP is expected to expand to US\$15.5 billion. Furthermore, the oil sector is projected to grow rapidly, accounting for around $40 \%$ of GDP by 2024 and supporting additional fiscal spending annually of $6.5 \%$ of non-oil GDP on average over the medium term [25]. Guyana's Stabroek Block is currently estimated to hold a recoverable resource exceeding 8 billion oil equivalent barrels [26]. According to Rystad Energy, estimates put Guyana's production at 1.2 million barrels per day by 2030 which could lead to the total national oil revenues generated reaching nearly US\$30 billion within a decade (https://www. rystadenergy.com/).

Importantly, on the January 23, 2019, Guyana's Natural Resource Fund (NRF) Act No. 12 of 2019 was enacted. This Act provides the legal framework for the establishment of "the Natural Resource Fund to manage the natural resource wealth of Guyana for the present and future benefit of the people and for the sustainable development of the country" Act No. 12 of 2019: Natural Resource Fund Act (p. 5) [27]. This will be enabled by means of: Ensuring that volatility in natural resource revenues or the revenues do not lead to volatile public spending nor a loss of economic competitiveness; transferring natural resource wealth across generations; and using the natural resource wealth as a source of funding for national development priorities. It is noteworthy that the NRF includes provisions for public oversight, management of the Fund, deposits and withdrawals including parliamentary ap- proval of withdrawals, determination of the amounts to be withdrawn, eligible assets into which the funds could be invested, and accounting, reporting and auditing.

Additionally, one can expect that the Fund will ensure accountability, transparency, international best practice and prudent management of resources derived from oil and gas. For instance, the Public Accountability Oversight Committee, would provide independent assessment of the management of the Fund and utilisation of withdrawals of the Fund; with representation from the civil society and community-based organisations, private sector, bar and media associations, women, youth, transparency associations, and academia among others, a wide cross-section of stakeholders would be involved in oversight of the Fund. Moreover, since the income generated from the Fund's investment will be used for national development initiatives, it could be argued that it would be used to strength the capacity constraints in the environment sector since that latter sector is a critical one for the country's development objectives.

The Fund received its first revenue of US\$54.93 million for the first 1 million barrels of oil on March 11, 2020. (Ministry of Finance) [28]. Subsequently, Guyana received about US\$35.03 million as payment for the second lift, which was recently deposited into NRF account. As at June 11, 2020, the total holdings of the NRF were approximately US\$94.9 million (Ministry of Finance) [28].

However, while the Government of Guyana has been pro-

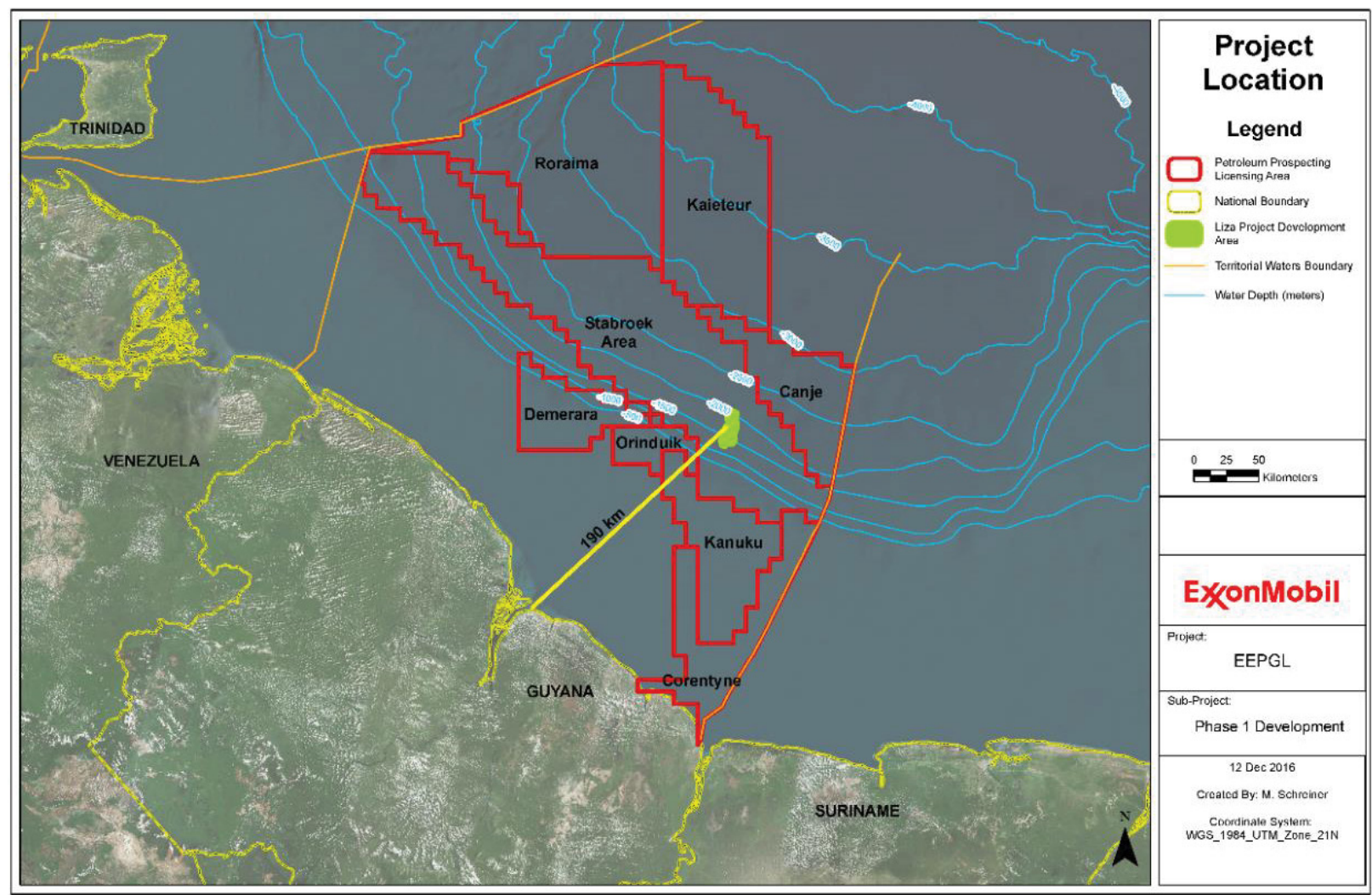

Figure 3: Location of Liza phase 1.

Source: Extracted from ERM (2017). 




Figure 4: Liza Phase I development field layout (Source: ExxonMobil) [75].

moting the energy sector as a critical and a strategic role in the development of Guyana's economy through improving the quantity, quality and reliability of the electricity supply (Chapter 39, National Development Strategy 2001-2010), it is the largest contributor of the country's greenhouse gas emissions. According to the Guyana Second National Communication (2012, p.62) on climate change issues, the Energy sector shows by far the greatest $\mathrm{CO}_{2}$ emissions derived from the electrical energy-generating sub-sector, with values ranging from $605 \mathrm{Gg}$ (42.1\%: 1990-1994) to 1,190 Gg (56.9\%: 2001). Hence, there an urgent need for a review of the EIA system in Guyana to ensure that there is balance between economic development and the protection of the environment from degradation and pollution, especially in light of Guyana's obligations as a signatory to the Rio Conventions, namely the United Nations Convention on biological Diversity (UNCBD), United Nations Convention to combat desertification (UNC$\mathrm{CD}$ ) and the United Nations Framework Convention on Climate Change (UNFCCC).

\section{Summary of the EIA Process in Guyana}

The EIA process was established as a legal requirement in Guyana with the passage of the country's Environmental Protection Act (Act No. 11 of 1996) which was amended in 2000. The Act also established the Environmental Protection Agency of Guyana (EPA) which is the competent authority for the EIA in the country, as well as the Environmental Assessment Board (EAB) which is an independent body that contributes to the development and finalisation of the EIA while ensuring that the interests of the developer, the public and regulatory agencies are upheld [29].

According to Part IV of the Act, the critical stages of the EIA process in Guyana include: screening to decide whether a proposed project should be subject to EIA; scoping to identify the important impacts and issues to be addressed and prepare terms of reference for the EIA study; EIA study and preparation of report; EIA review to assess the quality and adequacy of the EIA report; decision-making to approve or reject the proposed project and set the terms and conditions for implementation; follow up- to monitor, manage and audit the impacts of project implementation; and public consultation- to inform and consult with stakeholders throughout the EIA process (Figure 2) [16,17].

The EIA study comprises three components, namely:

- Environmental Baseline Study which is a record the present quality of the environment within the area of influence before project implementation;

- Environmental Assessment that analyses the baseline information to predict and evaluate potential impacts of the proposed project and of its alternatives and indicate the significance of the impacts. The EA also considers mitigation measures to avoid, reduce, remedy, compensate or offset negative impacts and assesses the impact of implementing the measures on the environment; and

- Environmental Impact Statement which is a summary of the Environmental Baseline Study and the Environmental Assessment and includes an Environmental Management Plan [29].

\section{Overview of the Case Study}

Four years after the discovery of oil (mentioned under section Prospects of the Oil and Gas Sector in Guyana), EEPGL, together with Hess Guyana Exploration Limited and CNOOC Nexen Petroleum Guyana Limited commenced production of hydrocarbons from the Liza field in December 2019 through the project "Liza Phase 1 Development Project" (Figure 3). This project proposes to produce 120,000 barrels per day over a 20-year period using a Floating Production Storage and Offloading (FPSO) vessel, the Liza Destiny, to process, store, and offload the recovered oil. There are 17 subsea development wells to which the FPSO is connected by associated equipment, referred to as subsea umbilicals, risers, and flowlines (SURF) (Figure 4). The latter transmits the produced fluids, i.e., oil, gas, produced water, from the production wells to the FPSO, as well as the treated gas and water from the 
FPSO to the injection wells. The project consists primarily of three phases, namely drilling and installation; production operations; and decommissioning as outlined below. It also involves shorebase facilities, and marine/aviation services to support these phases [30].

\section{Drilling and installation}

The 17 development wells include eight production wells (for recovering the oil), six water injection wells, and three gas injection wells to re-inject recovered gas that has not been used on the FPSO into the reservoir. For each drilled well, a wellhead and tree are installed and the well is connected to a manifold. The latter is connected to an umbilical and production, gas or water flowline which lays on the seafloor. The risers connect the seafloor infrastructure to the FPSO [30].

The FPSO, which has the capacity to store 1.6 million barrels of stabilised crude oil, is secured to the seafloor by a mooring anchor system that has been designed to keep the vessel in position for at least 20 years. Additionally, the FPSO provides accommodation and other facilities for the personnel working on it [30].

\section{Production operations}

The FPSO separates the fluids recovered from the reservoir into its oil, water and gas phases. While the oil is treated to remove impurities, such as sulphate and other salts, and then directed to storage tanks in the hull, the water (referred to as produced water) is treated to remove hydrocarbons and then discharged to the sea. The natural gas is dehydrated and compressed on the FPSO and re-injected into the Liza reservoir; some may be used as fuel on the FPSO and some may have to be flared. However, the latter is anticipated to be on a non-routine, temporary basis. The FPSO also treats sea water for injection into the reservoir to enhance oil production. On a regular basis, conventional oil tankers offload crude oil from the FPSO storage tanks using a floating hose [30].

\section{Decommissioning}

In the decommissioning stage, estimated at approximately 20 years, all development wells will be permanently plugged and abandoned in their current location on the seafloor. The FPSO will be disconnected from it mooring system and towed to a shipyard for decommissioning [30].

\section{Methodology}

The study utilised a qualitative methodology to generate detailed and valid (process) data that contribute to in-depth understanding of the context of the study. Patton [31] defined qualitative investigation as a process that begins with detailed narrative descriptions, that is then used to construct in-depth case studies of the issue under investigation and finally to compare and interpret the findings to arrive at patterns that cut across cases. To this end, two data collection methods

Table 2: Performance criteria for preparedness of EIA System for Oil and Gas in Guyana.

\begin{tabular}{|c|c|c|c|c|c|}
\hline $\begin{array}{l}\text { Criteria (include } \\
\text { justification for } \\
\text { criteria) }\end{array}$ & $\begin{array}{l}\text { Rationale for } \\
\text { Criteria }\end{array}$ & $\begin{array}{l}\text { Not at all } \\
\text { prepared } \\
(0)\end{array}$ & $\begin{array}{l}\text { Preparation in } \\
\text { embryonic stage (1) }\end{array}$ & Partially prepared (2) & $\begin{array}{l}\text { Fully prepared and } \\
\text { ready (3) }\end{array}$ \\
\hline $\begin{array}{l}\text { Policy for the } \\
\text { development of } \\
\text { oil and gas sector }\end{array}$ & $\begin{array}{l}\text { Provides vision, } \\
\text { guidance, } \\
\text { blueprint, } \\
\text { accountability, } \\
\text { efficiency and } \\
\text { clarity for sector } \\
\text { operation } \\
\text { and promotes } \\
\text { consistency in } \\
\text { decision and } \\
\text { actions of the } \\
\text { government }\end{array}$ & $\begin{array}{l}\text { No policy } \\
\text { exists for the } \\
\text { development of } \\
\text { the oil and gas } \\
\text { sector }\end{array}$ & $\begin{array}{l}\text { Policy is still in draft } \\
\text { form. }\end{array}$ & $\begin{array}{l}\text { Policy exists but it does } \\
\text { not have clear and explicit } \\
\text { provisions for the development } \\
\text { of the oil and gas sector }\end{array}$ & $\begin{array}{l}\text { Policy exists } \\
\text { that has clear } \\
\text { and explicit } \\
\text { provisions for the } \\
\text { development of the } \\
\text { oil and gas sector }\end{array}$ \\
\hline $\begin{array}{l}\text { Legislation for oil } \\
\text { and gas sector }\end{array}$ & $\begin{array}{l}\text { Critical to regulate } \\
\text { the oil and gas } \\
\text { industry/sector } \\
\text { with respect } \\
\text { particularly to } \\
\text { exploration and } \\
\text { production. }\end{array}$ & $\begin{array}{l}\text { No legislation } \\
\text { exists for the } \\
\text { development of } \\
\text { oil and gas sector }\end{array}$ & $\begin{array}{l}\text { Legislation is being } \\
\text { drafted. }\end{array}$ & $\begin{array}{l}\text { Legislation exists but does } \\
\text { not have clear and explicit } \\
\text { provisions for the development } \\
\text { of the oil and gas sector }\end{array}$ & $\begin{array}{l}\text { Legislation exists } \\
\text { that has clear } \\
\text { and explicit } \\
\text { provisions for the } \\
\text { development of the } \\
\text { oil and gas sector }\end{array}$ \\
\hline $\begin{array}{l}\text { Legislative } \\
\text { framework for } \\
\text { EIA - } \\
\text { Environmental } \\
\text { Protection (EP) } \\
\text { Act that addresses } \\
\text { the oil and gas } \\
\text { sector }\end{array}$ & $\begin{array}{l}\text { Critical to address } \\
\text { environmental } \\
\text { and social impacts } \\
\text { of oil and gas } \\
\text { exploration and } \\
\text { production }\end{array}$ & $\begin{array}{l}\text { EP Act does } \\
\text { not have any } \\
\text { provisions for the } \\
\text { EIA process for oil } \\
\text { and gas }\end{array}$ & $\begin{array}{l}\text { EIA legislation is in } \\
\text { draft/being drafted. }\end{array}$ & $\begin{array}{l}\text { EP Act has provisions for the } \\
\text { EIA process for oil and gas, but } \\
\text { it is not clear and explicit }\end{array}$ & $\begin{array}{l}\text { EP Act has clear } \\
\text { and explicit } \\
\text { provisions } \\
\text { (including steps } \\
\text { and requirements) } \\
\text { for the EIA process } \\
\text { for oil and gas }\end{array}$ \\
\hline
\end{tabular}




\begin{tabular}{|c|c|c|c|c|c|}
\hline $\begin{array}{l}\text { Awareness of } \\
\text { stakeholders of } \\
\text { EIA process }\end{array}$ & $\begin{array}{l}\text { Awareness can } \\
\text { enable persons to } \\
\text { act accordingly, as } \\
\text { well as be more } \\
\text { engaged in the EIA } \\
\text { process }\end{array}$ & $\begin{array}{l}\text { Stakeholders lack } \\
\text { awareness of } \\
\text { the EIA concept, } \\
\text { the role it plays } \\
\text { in development } \\
\text { approval and } \\
\text { its benefits } \\
\text { among most } \\
\text { stakeholders } \\
\text { (general public, } \\
\text { decision-making } \\
\text { authorities, } \\
\text { developers, etc.) }\end{array}$ & $\begin{array}{l}\text { Stakeholders have } \\
\text { very little awareness } \\
\text { of the EIA concept, } \\
\text { the role it plays } \\
\text { in development } \\
\text { approval and its } \\
\text { benefits among most } \\
\text { stakeholders (general } \\
\text { public, decision- } \\
\text { making authorities, } \\
\text { developers, etc.) }\end{array}$ & $\begin{array}{l}\text { Stakeholders have limited } \\
\text { awareness of the EIA } \\
\text { concept, the role it plays } \\
\text { in development approval } \\
\text { and its benefits among few } \\
\text { stakeholders (general public, } \\
\text { decision-making authorities, } \\
\text { developers, etc.) }\end{array}$ & $\begin{array}{l}\text { Stakeholders are } \\
\text { fully aware of } \\
\text { the EIA concept, } \\
\text { the role it plays } \\
\text { in development } \\
\text { approval and its } \\
\text { benefits among } \\
\text { most stakeholders } \\
\text { (general public, } \\
\text { decision-making } \\
\text { authorities, } \\
\text { developers, etc.) }\end{array}$ \\
\hline $\begin{array}{l}\text { Human resource } \\
\text { capacity at } \\
\text { the EPA and } \\
\text { institutions } \\
\text { related directly or } \\
\text { indirectly to the } \\
\text { management of } \\
\text { oil and gas sector }\end{array}$ & $\begin{array}{l}\text { This is important } \\
\text { as employees of } \\
\text { the EPA and other } \\
\text { institutions must } \\
\text { be empowered } \\
\text { with the requisite } \\
\text { knowledge and } \\
\text { skills to effectively } \\
\text { manage the oil and } \\
\text { gas sector. }\end{array}$ & $\begin{array}{l}\text { No professionals } \\
\text { trained at the } \\
\text { postgraduate } \\
\text { level in oil and gas } \\
\text { (at the EPA and } \\
\text { the institutions } \\
\text { related directly } \\
\text { or indirectly } \\
\text { to the oil and } \\
\text { gas sector), nor } \\
\text { do they have } \\
\text { experience in the } \\
\text { oil and gas sector }\end{array}$ & $\begin{array}{l}\text { There are written } \\
\text { plans to train } \\
\text { professionals at the } \\
\text { postgraduate level in } \\
\text { oil and gas (at the EPA } \\
\text { and the institutions } \\
\text { related directly or } \\
\text { indirectly to the oil } \\
\text { and gas sector) and } \\
\text { with some or no } \\
\text { experience in the oil } \\
\text { and gas sector }\end{array}$ & $\begin{array}{l}\text { Few professionals trained at } \\
\text { the postgraduate level in oil } \\
\text { and gas (at the EPA and the } \\
\text { institutions related directly or } \\
\text { indirectly to the oil and gas } \\
\text { sector) and with some or no } \\
\text { experience in the oil and gas } \\
\text { sector }\end{array}$ & $\begin{array}{l}\text { Adequate number } \\
\text { of professionals } \\
\text { trained at the } \\
\text { postgraduate level } \\
\text { in the oil and gas } \\
\text { (at the EPA and } \\
\text { the institutions } \\
\text { related directly or } \\
\text { indirectly to the } \\
\text { oil and gas sector) } \\
\text { and also with } \\
\text { experience in oil } \\
\text { and gas sector }\end{array}$ \\
\hline $\begin{array}{l}\text { Human resource } \\
\text { capacity for } \\
\text { conducting EIA } \\
\text { studies }\end{array}$ & $\begin{array}{l}\text { Having } \\
\text { professionals } \\
\text { with requisite } \\
\text { knowledge and } \\
\text { skills in conducting } \\
\text { ElAs is critical } \\
\text { to the effective } \\
\text { functioning of the } \\
\text { EIA system. }\end{array}$ & $\begin{array}{l}\text { No available } \\
\text { qualified } \\
\text { professionals with } \\
\text { the technical skills } \\
\text { and expertise } \\
\text { to carry out the } \\
\text { research and } \\
\text { preparation of an } \\
\text { ESIA report to the } \\
\text { necessary level to } \\
\text { inform decision } \\
\text { making }\end{array}$ & $\begin{array}{l}\text { Plans are being made } \\
\text { to recruit qualified } \\
\text { professionals with } \\
\text { the technical skills } \\
\text { and expertise to carry } \\
\text { out the research } \\
\text { and preparation of } \\
\text { an ESIA report to } \\
\text { the necessary level } \\
\text { to inform decision } \\
\text { making }\end{array}$ & $\begin{array}{l}\text { Few qualified professionals } \\
\text { available with the technical } \\
\text { skills and expertise to carry out } \\
\text { the research and preparation } \\
\text { of an ESIA report to the } \\
\text { necessary level to inform } \\
\text { decision making }\end{array}$ & $\begin{array}{l}\text { Adequate } \\
\text { availability } \\
\text { of qualified } \\
\text { professionals with } \\
\text { the technical skills } \\
\text { and expertise } \\
\text { to carry out the } \\
\text { research and } \\
\text { preparation of an } \\
\text { ESIA report to the } \\
\text { necessary level to } \\
\text { inform decision } \\
\text { making }\end{array}$ \\
\hline $\begin{array}{l}\text { Institutional } \\
\text { collaboration }\end{array}$ & $\begin{array}{l}\text { Institutional } \\
\text { collaboration } \\
\text { (sharing of } \\
\text { knowledge, skills, } \\
\text { resources etc.) is } \\
\text { a prerequisite to } \\
\text { an effective EIA } \\
\text { system. }\end{array}$ & $\begin{array}{l}\text { There exist no } \\
\text { collaborative } \\
\text { mechanisms (e.g., } \\
\text { MOUs) between } \\
\text { the EPA and } \\
\text { institutions that } \\
\text { relate directly } \\
\text { and indirectly to } \\
\text { the oil and gas } \\
\text { sector, but they } \\
\text { are not currently } \\
\text { functional }\end{array}$ & $\begin{array}{l}\text { Existence of } \\
\text { collaborative } \\
\text { mechanisms (e.g., } \\
\text { MOUs) between the } \\
\text { EPA and institutions } \\
\text { that relate directly } \\
\text { and indirectly to the } \\
\text { oil and gas sector, but } \\
\text { they are not currently } \\
\text { functional }\end{array}$ & $\begin{array}{l}\text { Some existing and functioning } \\
\text { collaborative mechanisms } \\
\text { (e.g., MOUs) between the EPA } \\
\text { and institutions that relate } \\
\text { directly and indirectly to the oil } \\
\text { and gas sector }\end{array}$ & $\begin{array}{l}\text { Existing and } \\
\text { functioning } \\
\text { collaborative } \\
\text { mechanisms (e.g., } \\
\text { MOUs) between } \\
\text { the EPA and } \\
\text { institutions that } \\
\text { relate directly and } \\
\text { indirectly to the oil } \\
\text { and gas sector }\end{array}$ \\
\hline
\end{tabular}



$5(1): 416-436$

\begin{tabular}{|c|c|c|c|c|c|}
\hline Baseline data & $\begin{array}{l}\text { Having data on the } \\
\text { current biological, } \\
\text { physical and } \\
\text { socioeconomic } \\
\text { conditions of } \\
\text { the areas with } \\
\text { the sphere of } \\
\text { influence of the } \\
\text { proposed project } \\
\text { is prerequisite } \\
\text { for impact } \\
\text { identification, } \\
\text { prediction etc. }\end{array}$ & $\begin{array}{l}\text { Absence of } \\
\text { baseline data } \\
\text { on the natural } \\
\text { and social } \\
\text { environment }\end{array}$ & $\begin{array}{l}\text { Some baseline data } \\
\text { on the natural and } \\
\text { social environment } \\
\text { available, but many } \\
\text { gaps still exist }\end{array}$ & $\begin{array}{l}\text { Some baseline data on the } \\
\text { natural and social environment } \\
\text { available, but a few gaps exist }\end{array}$ & $\begin{array}{l}\text { There is adequate } \\
\text { baseline data on } \\
\text { the natural and } \\
\text { social environment }\end{array}$ \\
\hline Risk management & $\begin{array}{l}\text { This is important } \\
\text { for long-term } \\
\text { planning that } \\
\text { will guarantee } \\
\text { protection } \\
\text { the health of } \\
\text { humans and the } \\
\text { environment }\end{array}$ & $\begin{array}{l}\text { Is not critical to } \\
\text { the EIA process/ } \\
\text { it is not required } \\
\text { by law }\end{array}$ & $\begin{array}{l}\text { Is being considered as } \\
\text { an optional element } \\
\text { of the EIA process, } \\
\text { but not a legal } \\
\text { requirement. }\end{array}$ & $\begin{array}{l}\text { Is legally required for projects, } \\
\text { but no clear guidelines exist }\end{array}$ & $\begin{array}{l}\text { Is required by } \\
\text { law and is often } \\
\text { integrated into the } \\
\text { EIA process with } \\
\text { guidelines provided }\end{array}$ \\
\hline $\begin{array}{l}\text { Use of } \\
\text { quantitative tools }\end{array}$ & $\begin{array}{l}\text { Quantitative tools } \\
\text { are important for } \\
\text { the evaluation } \\
\text { and prediction } \\
\text { of impacts in an } \\
\text { objective manner, } \\
\text { and for studying } \\
\text { cause effect } \\
\text { relationships of } \\
\text { project activities } \\
\text { and environmental } \\
\text { effects }\end{array}$ & $\begin{array}{l}\text { Use of analytical } \\
\text { tools, such as } \\
\text { mathematical } \\
\text { models and } \\
\text { Geographic } \\
\text { Information } \\
\text { Systems is not } \\
\text { practised in } \\
\text { impact analysis } \\
\text { studies }\end{array}$ & $\begin{array}{l}\text { Use of analytical } \\
\text { tools, such as } \\
\text { mathematical models } \\
\text { and Geographic } \\
\text { Information Systems } \\
\text { is practised in a few } \\
\text { selective impact } \\
\text { analysis studies }\end{array}$ & $\begin{array}{l}\text { Use of analytical tools, such } \\
\text { as mathematical models } \\
\text { and Geographic Information } \\
\text { Systems is practised in many } \\
\text { impact analyses studies }\end{array}$ & $\begin{array}{l}\text { Culture exists } \\
\text { regarding use } \\
\text { of analytical } \\
\text { tools, such as } \\
\text { mathematical } \\
\text { models and } \\
\text { Geographic } \\
\text { Information } \\
\text { Systems in all } \\
\text { impact analysis } \\
\text { studies }\end{array}$ \\
\hline $\begin{array}{l}\text { Stakeholder } \\
\text { engagement }\end{array}$ & $\begin{array}{l}\text { Stakeholder } \\
\text { engagement is a } \\
\text { legal requirement } \\
\text { and allows for } \\
\text { persons/groups } \\
\text { with interests } \\
\text { and influence } \\
\text { to participate in } \\
\text { the EIA process } \\
\text { through screening, } \\
\text { scoping, baseline } \\
\text { collection, } \\
\text { identification } \\
\text { of impacts, } \\
\text { mitigation, } \\
\text { alternatives, } \\
\text { review etc. }\end{array}$ & $\begin{array}{l}\text { There is no } \\
\text { practice of } \\
\text { stakeholder } \\
\text { engagement in } \\
\text { the EIA process. }\end{array}$ & $\begin{array}{l}\text { Is primarily the } \\
\text { provision of } \\
\text { information (one } \\
\text { way flow) to } \\
\text { assist the public in } \\
\text { understanding the } \\
\text { problem, alternatives, } \\
\text { opportunities and/or } \\
\text { solutions }\end{array}$ & $\begin{array}{l}\text { Is primarily the provision of } \\
\text { information and obtaining } \\
\text { public feedback (two-way flow) } \\
\text { on analysis, alternatives and/or } \\
\text { decisions }\end{array}$ & $\begin{array}{l}\text { Is primarily working } \\
\text { with the public } \\
\text { to ensure that } \\
\text { public concerns } \\
\text { are understood } \\
\text { and considered in } \\
\text { all stages (edit) in } \\
\text { decisions (about } \\
\text { project designs, } \\
\text { alternatives, } \\
\text { mitigation } \\
\text { measures and } \\
\text { project approval) }\end{array}$ \\
\hline
\end{tabular}


Citation: Bynoe P, Simmons D, (2021) A Critical Review of the Guyana EIA Process for the Emerging Oil and Gas Sector. Adv Environ Stud 5(1):416-436

\begin{tabular}{|c|c|c|c|c|c|}
\hline $\begin{array}{l}\text { Physical resource } \\
\text { capacity and } \\
\text { budget of the EPA } \\
\text { (environmental } \\
\text { authority) }\end{array}$ & $\begin{array}{l}\text { Adequate budget } \\
\text { and physical } \\
\text { resources are } \\
\text { essential to } \\
\text { the effective } \\
\text { implementation } \\
\text { of activities (e.g. } \\
\text { reconnaissance } \\
\text { visits, scoping } \\
\text { meetings, } \\
\text { compliance } \\
\text { monitoring of a } \\
\text { functional EIA } \\
\text { process. }\end{array}$ & $\begin{array}{l}\text { The EPA has no } \\
\text { physical resource } \\
\text { capacity to } \\
\text { carry out its EIA } \\
\text { mandate }\end{array}$ & $\begin{array}{l}\text { The EPA has very } \\
\text { limited physical } \\
\text { resource capacity } \\
\text { to carry out some } \\
\text { aspects of its EIA } \\
\text { mandate }\end{array}$ & $\begin{array}{l}\text { The EPA has very limited } \\
\text { physical resource capacity to } \\
\text { carry out most aspects of its } \\
\text { EIA mandate }\end{array}$ & $\begin{array}{l}\text { The EPA has } \\
\text { physical resource } \\
\text { capacity to carry } \\
\text { out all aspects of } \\
\text { its EIA mandate }\end{array}$ \\
\hline
\end{tabular}

were applied: Desk review of literature; and open ended, semi-structured interviews with regulators, consultants, as well as civil society and nongovernmental organisations in the pursuit of background information, experiences and institutional perspectives [32,33]. Professional judgement, based on knowledge and experience related to the conduct of EIAs was also utilised in the assessment.

\section{Desk review}

Desk review was considered as an important step in the collection of available and accessible secondary data. It involved the organising, analysing and synthesising information obtained froma wide range of secondary sources including Guyana's Environmental Protection Act, World Bank Group's guidelines for offshore oil and gas developments, United Nations Environment Programme documents and journal articles, and importantly, the Environmental Impact Statement (EIS)/EIA Report that legitimises this study which focuses on the EIA readiness in Guyana. Special attention was given to the EIA requirements, international best practice, environmental and social impacts associated with oil and gas production, plus the criteria for the assessment of the level of the EIA preparedness for the oil and gas sector.

\section{Semi-structured interviews}

The semi-structured face-to-face interview is recognised one of the most appropriate forms of, and commonly used qualitative techniques, since it provides a 'answers to the 'why' questions and aims to be a conversation which facilitates the imparting of expert knowledge of an issue, rather than test the knowledge or simply categorise [34]. First, a purposive sample comprising twenty-four (24) key informants/interviewees was selected from five broad categories: oil companies; regulators, such as Department of Energy, Department of Environment, Environmental Protection Agency, Guyana Energy Agency, Guyana Geology and Mines Commission and Ministry of Natural Resources; nongovernmental environmental organisations (World Wildlife Fund); civil society (Guyana Association of Professional Engineers); and EIA Consultants. The aim was to ensure maximum variation [35]. In each case, the key informant was a senior officer of the organisation.

Second, key informants were engaged by means of semi-structured interviews (guided conversations) that are considered a key technique and more flexible version than a structured interview in real world research $[34,36]$. Thus, a semi-structured interview schedule, comprising a set of pre-determined open-ended questions, was designed to solicit responses that enabled the assigning of values using specific criteria and indicators. Those values were considered critical to the determination of the aggregated level of preparedness of the EIA process in Guyana, with specific reference to the country's oil and gas sector, as shown in Table 2. Additionally, key informants were asked about their involvement directly or indirectly in the EIA process in Guyana, their knowledge of Part IV of the Environmental Protection Act of Guyana, specific actions Guyana has taken to enhance its capacities to implement and monitor EIAs for oil and gas sector, challenges the oil and gas sector, and specifically the ExxonMobil Liza Phase I project has presented for Guyana's EIA system, actions taken to address challenges, key lessons learnt from the implementation of the EIA for ExxonMobil Liza Phase I project, and their recommendations for the enhancement of Guyana's EIA system with respect to the oil and gas sector. The intention of the researchers was to explore the key informants' perspectives on the issues being investigated in an informal manner, and to allow flexibility in their responses [32,34]. Notably, category one (Not at all prepared) was included in Table 2 after the responses were initially analysed, in an effort to avoid any overlaps and to reflect more accurately the level of preparedness based on the responses expressed by twelve (12) key informants, representing $50 \%$. Non-responses by the remaining $50 \%$ of the key informants underscored the point made by Oppenheim [37] that interviewees may or may not have particular information or may have it, but are unable or unwilling to communicate it. The authors reviewed and discussed the scores assigned by the key informants, and agreed on the final score for each criterion.

\section{Analytical Framework}

We developed an analytical framework, based on theoretical insights and professional judgement, to assess the level of preparedness of the EIA process in Guyana for the emerging oil and gas sector, using twelve (12) criteria and four (4) broad indicators as the descriptors. Each descriptor was assigned a value to indicate the level of preparedness: Not at all prepared (0); Preparation in Embryonic stage (1); Partially prepared (2); and Fully prepared and ready (3). Prior to making a determination of the level of preparedness at the aggregate level, an assessment of each of the 12 criteria was 
done. Criteria ranged from policy development and enactment of legislation to stakeholder engagement and financial and other resources. Details are provided in Table 2. Similarly, at the aggregate level, four categories of preparedness were assigned, based on the following:

$$
\Sigma \mathrm{P}=\mathrm{C}_{1}+\mathrm{C}_{2}+\mathrm{C}_{3}+\ldots \ldots . .+\mathrm{C}_{12}
$$

Where $P$ is the aggregate level of preparedness based on the sum of the scores assigned to the 12 criteria.

$\mathrm{C}_{\mathrm{n}}$ is the specific criterion with the corresponding score, where the scores were assigned values 0 to 3 .

The range of scores for the level of preparedness at the aggregate level is 0 to 36 and the four categories of preparedness based on the scores are:

$\begin{array}{lll}\text { Not at all prepared } & = & 0-9 \\ \text { Preparation in embryonic stage }= & 10-18 \\ \text { Partially prepared } & = & 19-27 \\ \text { Fully prepared and ready } & = & 28-36\end{array}$

\section{Analysis and Discussion}

The findings revealed that at the aggregate level, preparedness of Guyana's EIA system for the Oil and Gas sector in Guyana was " 20 " indicating "partially prepared". At the disaggregate level, none of the criteria received the lowest rating of "not at all prepared" nor the highest rating of "fully prepared and ready". Of the 12 criteria assessed, 8 criteria were rated "partially prepared" and the remaining 4 criteria were rated "preparation in embryonic stage", the latter 4 criteria were: Policy for the development of oil and gas sector; institutional collaboration; baseline data; and physical resource capacity and budget of the EPA (environmental authority), as shown in Figure 5. Hereafter, we analyse and discuss the findings at the disaggregate level.

\section{Policy for the development of oil and gas sector}

A policy is critical to the effective and efficient development of the oil and gas sector in Guyana, as its clearly sets out the government's intention, priorities and the steps/actions to be taken to achieve stated goals and outcomes. It also provides that basis for the regulation of the sector. Guyana has a Petroleum (Exploration and Production) Act of 1986, which is described as An Act to make provision with respect to prospecting for and production of petroleum, and for matters connected therewith. Further, this Act 'applies to the exploration, exploitation, conservation and management of petroleum existing in its natural condition in land in Guyana, including the territorial sea, continental shelf and exclusive economic zone of Guyana'. There is also a Draft Energy Policy (2017), considered as the main policy that will governs the energy sector in Guyana, and presents an updated version of the 1994 National Energy Policy of Guyana. This policy provides broad guidelines on long term energy objectives and strategies, with a view to ensuring affordable, secure, efficient and sustainable supply of energy.



Criterion

Figure 5: Assessment results of preparedness of EIA system for oil and gas in Guyana. 
The draft policy also reflects on current national, regional and international commitments made by the Government of Guyana and its agencies up until 2016 and addresses continuing concerns related to the dependence on imported fossil fuels, the need to address the efficiency and sustainability of energy supply and demand, and the need to address climate change issues, plus the recent recognition of offshore petroleum reserves in 2015. As Annex A (4) of the Green State Development Strategy (GSDS-Vision 2040) notes "The potential of the oil industry in Guyana was only fully recognised in 2015 with ExxonMobil and EEPGL discovering over 90 meters of oil-bearing sandstone reservoir in the Liza 1 well in the Stabroek Block. This was followed by efforts on Liza2 well in July 2016 and Liza-3 well that discovered over one billion oil-equivalent barrels, confirming the Stabroek Block as a world-class oil resource". Neither of the energy policies presents clear and explicit provisions for the development of the oil and gas sector; hence the score of 2 . Further, one may argue that a general energy policy is adequate to provide the broader framework within which the Guyana oil and gas sector would develop.

(https://doe.gov.gy/published/document/5af72892dc677720ccdc33b8;

https://grdb.gy/wp-content/uploads/2019/07/A4-Transition-to-Renewable-and-Clean-Energy.pdf)

A very positive development has been the development of a Local Content policy that provides for the "active participation and development of Guyanese labour and suppliers in the petroleum sector and the benefits that arise from expenditure in the sector on labour, goods and services for Guyanese industry, the economy and wider society" [38]. The policy states that "the policy framework therefore precedes an overall petroleum sector policy for Local Content, and shall be updated from time to time to be aligned with a maturing petroleum sector and with evolving national development strategies and goals" [38]. This most recent policy document represents a very critical step for the government, as (Marcel, p.9) [39] contends that "It is particularly important for developing economies to devise petroleum-sector policies that maximize national development. For this purpose, governments must have clear local content objectives, which are set within a broader national vision."

\section{Legislation for oil and gas sector}

The oil and gas sector in Guyana is currently governed by the Petroleum (Production) Act, Cap 65:05; Petroleum (Exploration and Production) Act, Cap 65:10 (no. 3 of 1986); Petroleum (Exploration and Production) Regulations, 1986; and the Upstream Legal Requirements for Petroleum (2004). These are supported by the Guyana Geology and Mines Commission Act, the Environmental Protection Act and the Occupational Safety and Health Act. The recently passed NRF Act, has not yet been fully enforced, and there is the Petroleum Commission Bill. The earlier pieces of legislation are outdated and need to be revised "to support the transparency, governance, legal, regulatory and institutional frameworks for the oil and gas sector in Guyana" [40]. Consequently, this criterion was assigned a score of 2 since although legislation exists, it needs to have clear and explicit provisions for the development of the oil and gas sector. The areas that need focus include "oil revenue management, licensing, contract models (PSA), local content, and Health, Safety, Environmental and Social (HSES) management" [40]. Revision of the legal framework governing this sector is extremely critical to ensuring that the sector contributes to the wider economy, while avoiding the pitfalls of resource-rich countries [41].

\section{Legislative framework for EIA-Environmental Protection (EP) Act that addresses the oil and gas sector}

At the time of passage of the Environmental Protection Act in 1996 and the subsequent development of the guidelines in 2000 and 2004, there were no discoveries of commercial quantities of oil and gas in Guyana. As a consequence, the oil and gas sector was not included in Fourth Schedule of the Act which mandates developers of specific projects to apply to the EPA for an Environmental Permit, neither were any EIA guidelines developed for this sector, although guidelines exist for other sectors, such as the forestry, electricity and mining sectors.

Not with standing this, in respect of our case study, EEPGL submitted an application to the EPA for an Environmental Permit for the "Liza Phase 1 Development Project" in 2016, and following screening conducted by the Agency, an EIA was required for the project. Thus, EEGGL conducted an EIA study and the report was submitted in 2017. In fact, one key informant has posited that:

The manner in which the EP Act has been developed allows it to be applied to all sectors and associated projects which require environmental authorisation including the oil and gas sector... However, the terminology is not clear and explicit to the oil and gas sector. Likewise, the responsibilities of various stakeholders with the exception of the Environmental Assessment Board, is not clearly defined.

Hence, despite the absence of specific provisions for oil and gas projects in Guyana's EIA legislation, the fact that the Environmental Protection Act of 1996 could be applied to all sectors, inclusive of the oil and gas sector, resulted in the assigning of a score of 2 for this criterion. However, there needs to be emphasis on legal regulation and guidelines of EIA (which are currently being developed); Zhang, et al. [42] argue that procedure manuals, methodological guidelines, and refined and precise wording of the relevant legislation are essential for good practice in EIA. Jay, et al. [43] concurred that "the existence of published guidance on EIA procedures as a whole, or on particular elements of EIA, is clearly beneficial to carrying out EIA to certain standards" (p. 295).

Additionally, a review of EIA legislation from the two other jurisdictions, reveal that there are clear and explicit provisions for the oil and gas sector in the EIA legislation. Trinidad and Tobago's EIA legislation includes activities related to oil and gas, such as exploration for crude oil or natural gas, and the establishment of a facility for production of crude oil and/ or natural gas, as designated activities which require that the 
project proponent to apply for the country's Environmental Permit, referred to as a certificate of environmental clearance (Environmental Management Act Chapter 35:05) [44]. In Nigeria, EIA is a statutory requirement for all categories of oil and gas projects [45].

\section{Awareness of stakeholders of EIA process}

The Environmental Protection Act of 1996 recognises the right of every citizen of Guyana to be consulted in the EIA process. Moreover, Principle 10 of the Rio Declaration states that "environmental issues are best handled with participation of all concerned citizens" [19], and further identifies three important elements to public involvement: Access to information; opportunity to participate in the decision-making process; and effective access to administrative and judicial proceedings. However, our study has shown that there is limited awareness of the EIA concept, the role it plays in development process and its benefits among few stakeholders (general public, decision-making authorities, developers, among others), and thereby assigned a score of 2 . Importantly, stakeholder awareness is a pre-requisite for their participation in any effective EIA process. In fact, Chanchitpricha and Bond [46] argue that stakeholder participation serves three main purposes, namely obtaining public input, co-decision-making, and re-distribution of power in decision-making.

According to a key informant who is integrally involved in the process:

The EIA process is well known by the staff of the EPA. Sector Agencies are also aware of the process...however, the general public may not fully appreciate the role of the process as they're only involved through attendance to public scoping meetings.

The apparent lack of public awareness of the EIA process will limit the public's active involvement in the process; in fact, many persons have attended public consultations and scoping meetings only as recipients of information. It is therefore reasonable to assume that this issue is influenced by limitations of the Environmental Protection Act of 1996. (EP Act Cap. 20:05). (See discussion on stakeholder engagement).

\section{Human resource capacity at the EPA and insti- tutions related directly or indirectly to the man- agement of oil and gas sector}

There is no doubt that qualified and experienced human resources are needed in all steps of the EIA process from screening to monitoring and auditing [47-51]. Additionally, Zhang, et al. [42] also emphasised that competence and experience of EIA actors is important and play a key role when implementing EIA and not simply the number of human resources.

While the professionals at the EPA may have the expertise to administer the EIA process, there is the need for relevant expertise to understand the specific activities of oil and gas projects and their interactions with the social and environmental components, in order for these projects to be accurately screened, for the terms of reference for the EIA studies to capture the important issues and impacts, and for adequate reviews of EIA reports to be conduct, as well as for there to be regulatory monitoring.

In this study, one key informant noted that "postgraduate and even undergraduate training in oil and gas is quite limited in Guyana", while another indicated that:

There are a few individuals trained at post-graduate level in oil and gas/petroleum engineering but there is a lack of experience.

Furthermore, World Bank [40] noted that there is a shortage of oil and gas experts in the relevant ministries and departments of Guyana: The Department of Energy has a staff of eleven of which only five are trained in oil and gas; and the Guyana Geology and Mines Commission has only eight people trained in oil and gas. At the time of the study, only the Executive Director of the EPA possessed postgraduate training in oil and gas. Although there are preliminary initiatives undertaken and others proposed to increase the human resource capacities at the EPA and the relevant oil and gas sector agencies, the issues highlighted resulted in the assigning of a score of 2. It has been argued that lack of capacity exists widely as a common barrier for EIA practice in numerous jurisdictions [52-54].

\section{Human resource capacity for conducting EIA studies}

The EIA study of the proposed project (our ESPGL Case Study) was undertaken by "Environmental Resources Management (ERM)"- an international environmental and social consulting firm with considerable years of experience in the preparation of EIAs for offshore oil and gas development projects. The selection of the Consultants was constrained by the limited number of qualified professionals with the specific technical skills and expertise to conduct the research and preparation of an ESIA report to the necessary level to inform decision making, as depicted in the table with a score of 2 . Moreover, the limited human resource capacity, is characterised by operation of two local consultancy firms that have specialised expertise mostly in EIA studies for projects across forestry, infrastructure, mining and tourism sectors. According to a key informant:

There is a need for more experts to be trained in the oil and gas sector for conducting ESIAs to build local expertise. Also, persons should be trained in the review and report writing of ESIAs.

This view resonates with that of Clark [55] who states that "there is a lack of trained human resources and of financial resources that often leads to the preparation of inadequate and irrelevant EIA reports in developing countries", and observed by Wood [56] and Khosravi, et al. [57].

\section{Institutional collaboration}

The Environmental Protection Act of 1996 and its guidelines mandate that the EPA collaborate with a number of other institutions, referred to as sector agencies, in the EIA process in Guyana. The sector agencies are involved in screening, scoping and reviewing EIAs, as well as recommending terms 
and conditions that should be included in the Environmental Permit for a project. Further, institutional collaboration should continue during implementation of the project, where the EPA relies on the sector agencies to monitor compliance of the permitted project [29]. Some aspects of sector agency involvement in Guyana's EIA process are highlighted in Figure 2. Additionally, networking and collaboration is even more crucial for the effectiveness of an EIA in light of the fact that different institutions and ministries may have different or conflicting interests regarding EIA $[47,58]$.

Our study has shown that there are some existing and functioning collaborative mechanisms between the EPA and the institutions that relate directly and indirectly to the oil and gas sector, thus resulting in a score of 2 being assigned. While, at the time of the study, formal memoranda of understanding (MOUs) exist between EPA and a number of agencies, for example, GO-Invest, collaboration between the EPA and the sector agencies responsible for oversight and management of the oil and gas sector has occurred through informal arrangements and the hosting of workshops and meetings. Further, one key information who had an integral role in the EIA process in Guyana pointed to another aspect of institutional collaboration:

While the EIA process by design encourages institutional collaboration, the quality of such collaboration can be greatly improved. Such collaboration is mainly derived from sector and public scoping meeting aimed at developing Terms of References for the EIAs. The other major collaboration is attained through solicitation of comments on draft EIAs whereby the EPA writes sector agencies for comments. However, follow up from the EPA in this regard can be improved. Sector agencies rarely provide comments. For example, comments from key stakeholders on the EIA for Liza Phase 1 Project were notably absent.

The assertion by Alemagi, et al. [59] that competent and accredited personnel are essential to conduct a rigorous and objective EIA review process is likely a contributory factor for the absence of comments from some key local stakeholders in Guyana. In fact, the EPA utilised an international entity to assist with the review of the EIA for "Liza Phase 1 Project".

\section{Baseline data}

Baseline data is indispensable to the EIA process. It provides information on the current biological, physical and socio-economic conditions of the areas within the sphere of influence of the proposed project, and provides that basis for impact identification and prediction. Several prominent researchers and EIA proponents have argued that baseline may be regarded as that main support for the EIA process $[17,56,60-63]$, and more specifically, the environmental management plan (EMP) [64].

As in the case of Guyana, data on the social environment can be obtained through social surveys, desk review and key informants' interviews. In contrast, data is lacking on the natural environment, especially for offshore Guyana where wells are being drilled. Consequently, geophysical and biological data was acquired through studies commissioned by EEPGL to support project development. Since no previous baseline studies were conducted, the source of such data for regulatory purposes presented an inherent conflict of interest. Further, there are limitations to the data provided on biological resources due to the consultants' reliance, to a great extent, on existing grey literature that reveals knowledge gaps with respect to the natural environment. Additionally, the EPA provided no standard methodology for the collection of data on marine mammals and marine benthos; as such information was acquired over time through sighting by persons employed as Marine Mammal Observers by the EEPGL. According to the EIA document for Liza Phase 1 "Scientific data on marine fish in the PDA are sparse. Much of what is known about marine fishes offshore Guyana is known from study of commercial landings....Project-specific information on fish species from the PDA is available from observations made during EEPGL's various activities in the south-eastern half of the Stabroek Block since 2014".

All of the aforementioned issues resulted in a score of 1 being assigned. Other factors that may have resulted in the paucity of data on aspects of the environment include the rugged topography, accessibility to the ocean bed and high transportation cost.

\section{Risk management}

Risk management is part of the EIA process in Guyana; section 11 (5)(f) of the Environmental Protection Act of 1996 requires that each EIA include a description of any hazards or dangers which may arise from the project and an assessment of the risk to the environment. According to one key informant: "Risk assessment is required under the EP Act and forms part of the EIA document." In fact, risk assessment and management were included in the EIA for the Liza Phase 1 project. The risk assessment considered three types of unplanned events-hydrocarbon spill, vessel collision and onshore vehicular accident, and a risk matrix was used to evaluate the potential significance of these unplanned events. Since the first two unplanned events were "considered to have small, temporary, and localized impacts" [30], the assessment concentrated on the potential impacts from an oil spill. For the latter, oil spill modelling and coastal sensitivity mapping were conducted to characterise the resources/receptors with the potential to be exposed to oil. The oil spill modelling was performed for nine oil spill scenarios, including spills of different types of hydrocarbons and from different locations. Furthermore, an EEPGL Oil Spill Response Plan was developed that outlines plans and procedures, in the event of an oil spill incident, for action by EEPGL and other entities, such as the EPA, the Civil Defence Commission and the Guyana Coast Guard.

As a consequence of the foregoing, risk management was assigned a score of 2, indicating that it is legally required for projects, but no clear guidelines exist. It has been argued that although currently there is no widely accepted risk assessment methodology, incorporating them-particularly the semi-quantitative or qualitative techniques - into the EIA process would increase the objectivity of the process [65]. 


\section{Use of quantitative tools}

The assignment of a score of 1 for the use of quantitative tools such as mathematical models and geographic information systems (GIS) indicates practice is only common to a few selective impact analysis studies, including the "Liza Phase 1 Development Project EIA". For example, Modelling of the deposition of cuttings and fluids was performed using the Generalized Integrated Fate and Transport (GEMSS-GIFT) model. Air dispersion modelling, using the CALPUFF model (a non-steady-state model used in the U.S. and around the globe for long-range transport and complex wind modelling) was selected for use in the assessment was carried out to assess air quality impacts for onshore human receptors. Additionally, quantitative tools are often cited in EIA studies that include risk assessments in which more than 90 per cent would exclude from their submissions. Key informants cited three factors responsible for the observed trend as paucity of and limited accessibility to data, limited technical capacities, and absence of efficient hardware to produce the models.

Unarguably, quantitative models (mathematical and computer software models, such as air dispersion models, hydrological models, and ecological models) are necessary for more accurate prediction of impact magnitude in EIA studies, as they help to explain the environment as a system and to study the effects of different environmental components through cause-effect relationships, and to make predictions about their behaviours [66-68]. In the context of the EIA process in Guyana, the use of such models will generate scientific information necessary for more evidence-based decision-making by both policy makers and regulators.

Table 3: Assessment results of preparedness of EIA system for oil and gas in Guyana.

\begin{tabular}{|c|c|c|}
\hline Criteria & $\begin{array}{l}\text { Level of } \\
\text { Preparedness } \\
\text { Score }\end{array}$ & Level of Preparedness Indicator \\
\hline $\begin{array}{l}\text { Policy for the development of oil and } \\
\text { gas sector }\end{array}$ & 2 & $\begin{array}{l}\text { Policy exists, but it does not have clear and explicit } \\
\text { provisions for the development of the oil and gas sector }\end{array}$ \\
\hline Legislation for oil and gas sector & 2 & $\begin{array}{l}\text { Legislation exists, but does not have clear and explicit } \\
\text { provisions for the development of the oil and gas sector }\end{array}$ \\
\hline $\begin{array}{l}\text { Legislative framework for EIA - } \\
\text { Environmental Protection (EP) Act that } \\
\text { addresses the oil and gas sector }\end{array}$ & 1 & $\begin{array}{l}\text { EP Act does not have any provisions for the EIA process for } \\
\text { oil and gas }\end{array}$ \\
\hline $\begin{array}{l}\text { Awareness of stakeholders of EIA } \\
\text { process }\end{array}$ & 2 & $\begin{array}{l}\text { Stakeholders have limited awareness of the EIA concept, } \\
\text { the role it plays in development approval and its benefits } \\
\text { among few stakeholders (general public, decision-making } \\
\text { authorities, developers, etc.) }\end{array}$ \\
\hline $\begin{array}{l}\text { Human resource capacity at the EPA } \\
\text { and institutions related directly or } \\
\text { indirectly to the management of oil and } \\
\text { gas sector }\end{array}$ & 2 & $\begin{array}{l}\text { Few professionals trained at the postgraduate level in oil } \\
\text { and gas (at the EPA and the institutions related directly or } \\
\text { indirectly to the oil and gas sector) and with some or no } \\
\text { experience in the oil and gas sector }\end{array}$ \\
\hline $\begin{array}{l}\text { Human resource capacity for } \\
\text { conducting EIA studies }\end{array}$ & 2 & $\begin{array}{l}\text { Few qualified professionals available with the technical skills } \\
\text { and expertise to carry out the research and preparation of } \\
\text { an ESIA report to the necessary level to inform decision } \\
\text { making }\end{array}$ \\
\hline Institutional collaboration & 2 & $\begin{array}{l}\text { Some existing and functioning collaborative mechanisms } \\
\text { (e.g., MOUs) between the EPA and institutions that relate } \\
\text { directly and indirectly to the oil and gas sector }\end{array}$ \\
\hline Baseline data & 1 & $\begin{array}{l}\text { Some baseline data on the natural and social environment } \\
\text { available, but many gaps still exist }\end{array}$ \\
\hline Risk management & 2 & Is legally required for projects, but no clear guidelines exist \\
\hline Use of quantitative tools & 1 & $\begin{array}{l}\text { Use of analytical tools, such as mathematical models and } \\
\text { Geographic Information Systems is practised in a few } \\
\text { selective impact analysis studies }\end{array}$ \\
\hline Stakeholder engagement & 2 & $\begin{array}{l}\text { Is primarily the provision of information and obtaining public } \\
\text { feedback (two-way flow) on analysis, alternatives and/or } \\
\text { decisions }\end{array}$ \\
\hline $\begin{array}{l}\text { Physical resource capacity and budget } \\
\text { of the EPA (environmental authority) }\end{array}$ & 1 & $\begin{array}{l}\text { The EPA has very limited physical resource capacity to } \\
\text { carry out some aspects of its EIA mandate }\end{array}$ \\
\hline Total score & 20 & \\
\hline
\end{tabular}




\section{Stakeholder engagement}

The engagement of stakeholders, especially central and local government, community and indigenous organisations, is a critical step in the EIA process as it fosters a sense of ownership, and promotes transparency and accountability of the part of government officials [69] who are tasked with managing the oil and gas sector in Guyana. See also discussion on stakeholder awareness of the EIA process.

Stakeholder engagement, with reference to the "Liza Phase 1 Development Project", constituted A public consultation programme aimed to inform the public about the Project and to get an understanding of stakeholders' concerns that could be incorporated into the EIA, as applicable.

The specific objectives were identified as follows:

i. Promote the development of respectful and open relationships between stakeholders and EEPGL during the Project life cycle; and

ii. Identify Project stakeholders and understand their interests and concerns in relation to Project activities; and incorporate such interests and concerns into the EIA and ESMP development processes, and, if appropriate, the Project design.

The EEPGL, through their Consultants, facilitated various workshops with the government and others regarding offshore oil and gas development, held meetings with over 30 central and local government agencies/commissions, over 15 professional or business associations, various international and domestic non-governmental organizations, universities and research institutes, various religious and ethnic organizations, and the media. Additionally, both EEPGL and ERM participated in two sector agency scoping meetings, with over 150 attendees of which approximately 100 were members of the general public. These were supplemented by six public scoping meetings in Administrative Regions 1 through 6, at which there were more than 300 attendees, two-third being public participants. Thus, the nature of engagement was primarily the provision of information and obtaining public feedback (two-way flow) on issues and concerns related to impacts, analysis, alternatives and/or decisions, earning it a score of 2.

Key informants noted that attendance at public scoping events that usually target entire administrative regions (for offshore oil production) does not attract numerous individuals (in comparison to population) and feedback is quite limited due to the lack of public awareness and understanding of processes involved in the oil and gas project. Specific concerns raised include (i) Consultation period may not be sufficient to conduct a robust stakeholder engagement process for adequate feedback; (ii) There is a deficiency in the EIAs to address social and cultural issues; and (iii) The lack of appropriate protocols and timelines, ensuring adequate information flow for informed decision making and reaching for the ideals of Free Prior Informed Consent, especially in indigenous, traditional and rural communities in Guyana.

Another limitation is the absence of other measures to achieve higher forms of public engagement such as involve- ment, collaboration, and empowerment as posited by Jones [70] in the "The Art of Consultation" [70]. It is noteworthy that the Environmental Protection Act of 1996 makes limited provision for a comprehensive stakeholder engagement process [71]; however, this is required to promote as public trust, empowerment of stakeholders, fair and holistic environmental decisions, social learning, higher quality information, sense of ownership, improved implementation of decisions, among other benefits [72].

\section{Physical resource capacity and budget of the EPA (environmental authority)}

Ahmad and Wood [47], Androulidakis and Karakassis [49], Toro, et al. [50] and Wood, et al. [51] have argued that qualified and experienced personnel, as well as financial support, are the most crucial factors for successful monitoring. Further, Glasson and Salvador [73] reported that for the EIA system in Brazil, there are very few trained and skilled personnel and material resources.

According to one key informant, there is an "insufficient budget" and "no equipment to monitor', while another informant posited that the:

Budget is dependent on approval from Central government. Revenue earned from applications and permits are not sufficient. Facilities and equipment are a function of adequate financial resources."

Consequently, this criterion was assigned a score of 1 , indicating that the EPA has very limited physical resource capacity to carry out some aspects of its EIA mandate. The limited resources affects the EPA's ability to execute independent compliance and impact monitoring, thus resulting in the Agency being unable to establish whether the oil and gas companies are in compliance with the terms and conditions of the Environmental Permits or validate predictions made in the EIA studies or identify the occurrence of unanticipated impacts. Rather, the EPA would need to rely on the oil and gas companies and/or sector agencies to provide the necessary information. Moreover, the EPA would need sample collection and measurement equipment, as well as the services of a laboratory so that it could scientifically measure the parameters that have been identified for monitoring. This is supported by Alemagi [74] who posited that the procurement of "adequate human, financial and technical resources for monitoring industrial effluents" (p. 143) is essential for the oil industry in Cameroon. The fact that the Liza Phase 1 Project is offshore also presents a particular challenge for the Agency accessing the EEPGL's operations.

\section{Summary table}

Table 3 summarises the analysis of the level of preparedness of the Guyana EIA process, using the analytical framework presented above.

\section{Conclusion}

Based on the criteria that were developed to guide the assessment, the Guyana EIA system is partially prepared for the oil and gas sector. This can be validated by the fact that 
the country has no historical experience in dealing with that sector, and is therefore required to create and maintain the enabling institutional architecture that would allow the national competent authority (the Environmental Protection Agency) to monitor and manage environmental and social impacts that may result from oil and gas production. The key findings are re-emphasised below:

- The Local Content Policy is a step in the right direction as it provides the framework for Guyanese citizens to participate as labourers and service providers and ultimately augment their socio-economic standards.

- The Energy Policy has not been finalised; as such, there is not a clearly articulated vision for the holistic development of the oil and gas sector in Guyana.

- Lack of awareness of the EIA process in Guyana undermines effective stakeholder engagement.

- There is a paucity of environmental data that limits the extent to which quantitative models can be used. Additionally, the regulator has to depend on the developer for environmental data and this can compromise the decision-making process.

- The EIA legislation does not require stakeholder engagement beyond consultation, which is insufficient for meaningful participation in the decision-making for the development project.

- While the recently passed NRF Act and the development of Petroleum Commission Bill are initial steps, the other pieces of oil and gas legalisation require updating/revision.

- There is the absence of specific provisions for the oil and gas sector in EIA legislation and guidelines of Guyana.

- There is a limited number of oil and gas experts in the relevant ministries and departments of Guyana which can compromise the management of the oil and gas sector. The EPA also has very limited physical resource capacity (including finances and equipment) to carry out some aspects of its EIA mandate, such as monitoring.

- Risk management is required by law and is part of the EIA process, although there is no guidance for conducting risk assessments and the methodologies used vary.

The assessment results presented in this article are therefore vital to a review process of Guyana's current EIA system, with specific reference to risk assessment and management, stakeholder engagement, specific sector guidelines, together with the formulation of clear policies and regulations. Additionally, there should be a sense of urgency to consider the following recommendations aimed at supporting a robust, national EIA system that can guarantee present and future generations a clean and healthy environment, while supporting their socio-economic development.

\section{Recommendations}

With regard to the issues outlined above, the following recommendations are made.
- Formalise institutional framework/arrangements regarding collaboration in the oil and gas sector in Guyana.

- Develop, with maximum stakeholder input, a robust Local Content Policy that will be just and fair to the Guyanese populace.

- Review and update the current Energy Policy that articulates a clear vision for the holistic development of the oil and gas sector in Guyana, and factors in current environmental concerns

- Develop, implement and sustain a comprehensive public awareness and education campaign centred on the EIA process and the expected role of stakeholders.

- Build the capacity of staff and improve the data management systems of the EPA and other agencies such as the Guyana Geology and Mines Commission, as well as review and revise the data sharing protocols.

- Provision of adequate financial and technical resources for the EPA to improve the Agency's ability to effectively execute the Agency's EIA mandate from screening to monitoring and auditing. To this end, indicators and standards should be developed.

- Review and update the EIA legislation and guidelines to reflect the current economic development trajectory of Guyana, in addition to issues such as risk assessment, cumulative effects assessment and stakeholder engagement.

- Conduct an assessment of the oil projects to climate change, given Guyana's obligations to the United Nations Framework Convention on Climate Change.

\section{References}

1. Morozov IV, Potanina YM, Voronin SA, et al. (2018) Prospects for the development of the oil and gas industry in the regional and global economy. International Journal of Energy Economics and Policy 8: 55-62.

2. Mitchell J, Marcel V, Mitchell B (2012) What next for the oil and gas industry? Chatham House, The Royal Institute of International Affairs, London.

3. Doric B, Dimovski V (2018) Managing petroleum sector performance-A sustainable administrative design. Economic Research-Ekonomska Istraživanja 31: 119-138.

4. Kemal M (2016) Ownership rights versus access rights allocation to critical resources: An empirical study of the economic impact of changes in oil governance.

5. Boohene R, Peprah JA (2011) Women, livelihood and oil and gas discovery in Ghana: An exploratory study of Cape three points and surrounding communities. Journal of Sustainable Development 4: 185-195.

6. Adewuyi AO, Oyejide TA (2012) Determinants of backward linkages of oil and gas industry in the Nigerian economy. Resources Policy 37: 452-460.

7. Baptiste AK, Nordenstam BJ (2009) Impact of oil and gas drilling in Trinidad: Factors influencing environmental attitudes and behaviours within three rural wetland communities. Environmental Conservation 36: 14-21. 
8. Barker A, Jones C (2013) A critique of the performance of EIA within the offshore oil and gas sector. Environmental Impact Assessment Review 43: 31-39.

9. Camphuysen CJ, Heubeck M (2001) Marine oil pollution and beached bird surveys: The development of a sensitive monitoring instrument. Environ Pollut 112: 443-461.

10. Cordes EE, Jones DOB, Schlacher TA, et al. (2016) Environmental impacts of the deep-water oil and gas industry: A review to guide management strategies. Front Environ Sci 4: 1-26.

11. E\&P Forum/UNEP (1997) Environmental management in oil and gas exploration and production. An overview of issues and management approaches. UNEP IE/PAC Technical Report 37, Oxford, UK.

12. World Bank Group (2015) Environmental, health, and safety guidelines for offshore oil and gas development.

13. Isah MN (2012) The role of environmental impact assessment in Nigeria's oil and gas industry. Cardiff University.

14. Sachs LE, Maennling N, Perrine T (2017) How oil and gas companies can help meet the global goals on energy and climate change.

15. Klees R, Capcelea A, Barannik A (2002) Environmental impact assessment (EIA) systems in Europe and Central Asia Countries. The World Bank.

16. United Nations Environment Programme (UNEP) (2002) Topic 1-Introduction and overview of EIA. In: Environmental impact assessment training resource manual. ( $\left.2^{\text {nd }} \mathrm{edn}\right), 101-131$.

17. Glasson J, Therivel R, Chadwick A (2012) Introduction to environmental impact assessment (Natural and built environment series). ( $4^{\text {th }}$ edn), Routledge.

18. International Association for Impact Assessment (IAIA) (2009) What is impact assessment?

19. United Nations General Assembly (1992) Report on the United Nations conference on environment and development.

20. Fasina OA (2016) Environmental impact assessment for oil and gas projects: A comparative evaluation of Canadian and Nigerian Laws. The University of Western Ontario.

21. Durden JM, Lallier LE, Murphy K, et al. (2018) Environmental Impact Assessment process for deep-sea mining in 'the area'. Marine Policy 87: 194-202.

22. Budd M (1999) The application of environmental assessment to marine developments and activities in Great Britain. Marine Policy 23: 439-451.

23. Salter E, Ford J (2000) Environmental pollution challenges and associated planning and management issues facing offshore oil and gas field development in the UK. Journal of Environmental Planning and Management 43: 253-276.

24. Human Development Report (2020) The next frontier: Human development and the anthropocene.

25. International Monetary Fund (2019) IMF executive board concludes 2019 article IV consultation with Guyana.

26. Oil Now (2020) Guyana's 8 billion plus barrels of oil only tip of the iceberg-Ramnarine.

27. (2019) Act No. 12 of 2019: Natural resource fund act.

28. Ministry of Finance (2020) Budget speech, ministry of finance, Georgetown.

29. Environmental Protection Agency/Environmental Assessment
Board (EPA/EAB) (2004) Environmental impact assessment guidelines, Volume 1: Rules and procedures for conducting and reviewing EIAs.

30. ERM (2017) Environmental impact assessment: Liza phase I development project-esso exploration and production, Guyana, Limited.

31. Patton MQ (2002) Qualitative research and evaluation methods. $\left(3^{\text {rd }}\right.$ edn), Sage Publications, Thousand Oaks.

32. Creswell JW, Creswell JD (2018) Research design: Qualitative, quantitative and mixed methods approaches. ( $5^{\text {th }}$ edn), SAGE Publications Inc.

33. Hammarberg K, Kirkman M, de Lacey S (2016) Qualitative research methods: When to use them and how to judge them. Human Reproduction 31: 498-501.

34. Bryman A (2016) Social research methods. Oxford University Press.

35. Alsaawi A (2014) A critical review of qualitative interviews. European Journal of Business and Social Sciences 3: 149-156.

36. Gillham B (2000) Case study research methods. Continuum.

37. Jong YO, Jung CK (2015) The development of interview techniques in language studies: Facilitating the researchers' views on interactive encounters. English Language Teaching 8: 30-39.

38. Government of Guyana (2020) Guyana petroleum sector: Realising local content benefits and value retention from Guyana's petroleum resources-local content policy.

39. Marcel V (2016) Guidelines for good governance in emerging oil and gas producers 2016. Chatham House: The Royal Institute of International Affairs.

40. World Bank (2019) International development association project appraisal document on a proposed credit in the amount of SDR 14,300,000 (US\$20 million equivalent) to the Co-operative Republic of Guyana for a Guyana petroleum resources governance and management project.

41. Leon P (2019) Regulation of SA oil sector and a new petroleum resources bill. politicsweb.

42. Zhang J, Kørnøv L, Christensen P (2013) Critical factors for ElA implementation: Literature review and research options. J Environ Manage 114: 148-157.

43. Jay S, Jones C, Slinn P, et al. (2007) Environmental impact assessment: Retrospect and prospect. Environmental Impact Assessment Review 27: 287-300.

44. (2000) Environmental management act. Laws of Trinidad and Tobago. Ministry of the Attorney General and Legal Affairs.

45. Anyadiegwu $\mathrm{Cl}$ (2012) Overview of environmental impact assessment of oil and gas projects in Nigeria. AFRREV STECH: An International Journal of Science and Technology 1: 66-80.

46. Chanchitpricha C, Bond A (2013) Conceptualizing the effectiveness of impact assessment processes. Environmental Impact Assessment Review 43: 65-72.

47. Ahmad B, Wood C (2002) A comparative evaluation of the EIA systems in Egypt, Turkey and Tunisia. Environmental Impact Assessment Review 22: 213-234.

48. Ali OMM (2007) Policy and institutional reforms for an effective EIA system in Sudan. Journal of Environmental Assessment Policy and Management 9: 67-82. 
49. Androulidakis I, Karakassis I (2006) Evaluation of the EIA system performance in Greece, using quality indicators. Environmental Impact Assessment Review 26: 242-256.

50. Toro J, Requena I, Zamorano M (2010) Environmental impact assessment in Colombia: Critical analysis and proposals for improvement. Environmental Impact Assessment Review 30: 247261.

51. Wood C, Dipper B, Jones CE (2000) Auditing the assessment of the environmental impacts of planning projects. Journal of Environmental Planning and Management 43: 23-47.

52. Ahammed R, Harvey N (2004) Evaluation of environmental impact assessment procedures and practice in Bangladesh. Impact Assessment and Project Appraisal 22: 63-78.

53. Kahangirwe $P$ (2011) Evaluation of environmental impact assessment (EIA) practice in Western Uganda. Impact Assessment and Project Appraisal 29: 79-83.

54. Ogunba OA (2004) EIA systems in Nigeria: Evolution, current practice and shortcomings. Environmental Impact Assessment Review 24: 643-660.

55. Clark BD (1999) Capacity building. In: J Petts, Handbook of Environmental Impact Assessment. (edn), Volume 2, Blackwell.

56. Wood C (2003) Environmental impacts assessment in developing countries. International Development Plan Review 25: 301-321.

57. Khosravi F, Jha TU, Fischer TB (2019) Evaluation of the environmental impact assessment system in Iran. Environmental Impact Assessment Review 74: 63-72.

58. Loon L, Driessen P, Kolhoff A, et al. (2010) An analytical framework for capacity development in EIA-The case of Yemen. Environmental Impact Assessment Review 30: 100-107.

59. Alemagi $D$ (2007) The oil industry along the Atlantic coast of Cameroon: Assessing impacts and possible solutions. Resources Policy 32: 135-145.

60. Carroll B, Turpin T (2009) Environmental impact assessment handbook. ( $2^{\text {nd }}$ edn), Thomas Telford Ltd.

61. Lawrence DP (2003) Environmental impact assessment: Practical solutions to recurrent problems. John Wiley \& Sons.

62. Morris P, Therivel R (2009) Methods of environmental impact assessment. ( ${ }^{\text {rd }}$ edn), Routledge.
63. Wathern P (1992) Environmental impact assessment: Theory and practice. Routledge.

64. Edwin WNL, Sunday VN (2016) A baseline environmental impact assessment (EIA) of proposed sit for thermal desorption unit (TDU) waste management project in Rivers State, Nigeria: Floristic composition approach. American Journal of Bioscience and Bioengineering 4: 9-25.

65. Fuentes BJL, Bastante CMJ, Ferrer GPS, et al. (2020) Study of major-accident risk assessment techniques in the environmental impact assessment process. Sustainability 12: 5770.

66. Okpala AN, Yorkor B (2013) A review of modelling as a tool for environmental impact assessment. International Research Journal in Engineering, Science and Technology 10: 39-46.

67. United Nations University (UNU), UNEP, \& RMIT (2007) Environmental impact assessment (EIA)-open educational resource.

68. Walker L, Johnston J (1999) Guidelines for the assessment of indirect and cumulative impacts as well as impact interactions. Report for European Commission.

69. Vasquez PI (2016) Four policy actions to improve local governance of the oil and gas sector. International Development Policy/Revue internationale de politique de développement.

70. Gammell E, Jones R (2009) The art of consultation. Biteback Publishing.

71. Bynoe ML (2006) Citizen participation in the environmental impact assessment process in Guyana: Reality or fallacy? Law Environment and Development Journal 2: 34-49.

72. Dagiliute R, Juozapaitiene G (2018) Stakeholders in the EIA process: What is important for them? The case of road construction. Environmental and Climate Technologies 22: 69-82.

73. Glasson J, Salvador NNB (2000) EIA in Brazil: A procedures-practice gap. A comparative study with reference to the European Union, and especially the UK. Environmental Impact Assessment Review 20: 191-225.

74. Alemagi D, Sondo VA, Ertel J (2007) Constraints to environmental impact assessment practice: A case study of Cameroon. Journal of Environmental Assessment Policy and Management 9: 357-380.

75. ExxonMobil (2020) Guyana project overview. 
Appendix 1: More detailed description of adverse environmental and social impacts of offshore oil and gas industry.

\begin{tabular}{|c|c|}
\hline Phase/Activity & Key environmental and social impact \\
\hline \multicolumn{2}{|l|}{ Aquatic environment } \\
\hline - Exploration/seismic survey \& drilling and appraisal & Generation of noise from seismic equipment and well drilling \\
\hline - Exploration/seismic survey \& drilling and appraisal & Generation of light from seismic equipment and well drilling \\
\hline - Exploration/seismic survey & $\begin{array}{l}\text { Changes in water quality due to discharges to ocean from bilges and sewage } \\
\text { due to vessel operations }\end{array}$ \\
\hline - Exploration/seismic survey & Changes in water quality due to spillages from vessel operations \\
\hline $\begin{array}{l}\text { - Exploration/drilling and appraisal } \\
\text { - Development and production/process and storage }\end{array}$ & $\begin{array}{l}\text { Changes in water quality associated with drilling discharges (drill cuttings, } \\
\text { drilling fluids, cement), wash water, deck drainage water, hydrostatic testing } \\
\text { water, produced water, sewage, sanitary and kitchen wastes, bilge water, } \\
\text { ballast water, cooling water, spillages and leakages from well drilling and other } \\
\text { general operations, and those operations associated with process and storage }\end{array}$ \\
\hline - Exploration/drilling and appraisal & Changes in the composition and structure of the seabed due to drilling \\
\hline \multicolumn{2}{|r|}{ Atmospheric environment } \\
\hline - Exploration/seismic survey \& drilling and appraisal & $\begin{array}{l}\text { Changes in ambient air quality due to emissions from combustion of fuels in } \\
\text { vessel engines (and including helicopters) }\end{array}$ \\
\hline $\begin{array}{l}\text { - } \quad \text { Exploration/drilling and appraisal } \\
\text { - Development and production/process and storage }\end{array}$ & $\begin{array}{l}\text { Changes in ambient air quality arising from flaring, venting, purging gases, } \\
\text { combustion of fuels in turbines, engines or boilers during drilling and } \\
\text { associated operations, and process and storage }\end{array}$ \\
\hline - Exploration/drilling and appraisal & $\begin{array}{l}\text { Changes in ambient air quality associated with particulate matter from } \\
\text { disturbed seabeds and burning sources, e.g., well testing }\end{array}$ \\
\hline $\begin{array}{l}\text { - Exploration/drilling and appraisal } \\
\text { - Development and production/process and storage }\end{array}$ & Generation of noise from drilling, facilities and flaring \\
\hline $\begin{array}{l}\text { - Exploration/drilling and appraisal } \\
\text { - Development and production/process and storage }\end{array}$ & Generation of light from drilling, facilities and flaring \\
\hline \multicolumn{2}{|r|}{ Terrestrial environment } \\
\hline $\begin{array}{l}\text { - Exploration/seismic survey \& drilling and appraisal } \\
\text { - Development and production/process and storage }\end{array}$ & $\begin{array}{l}\text { Changes in soil quality due to spillages, generation of solid waste and garbage } \\
\text { to shore during the vessel operations, drilling and associated operations, and } \\
\text { decommissioning }\end{array}$ \\
\hline \multicolumn{2}{|r|}{ Biological environment } \\
\hline $\begin{array}{l}\text { - Exploration/seismic survey \& drilling and appraisal } \\
\text { - Development and production/process and storage }\end{array}$ & $\begin{array}{l}\text { Disturbance to marine organisms (benthic \& pelagic) and birds from seismic } \\
\text { equipment, drilling operations and decommissioning }\end{array}$ \\
\hline \multicolumn{2}{|r|}{ Social environment } \\
\hline $\begin{array}{l}\text { - Exploration/seismic survey \& drilling and appraisal } \\
\text { - } \quad \text { Development and production/process and storage }\end{array}$ & $\begin{array}{l}\text { Lack of/limited access to natural capital by other resource users (e.g., } \\
\text { fisherfolk) }\end{array}$ \\
\hline All phases and activities & Changes in locate population levels as a result of immigration (labour force) \\
\hline All phases and activities & $\begin{array}{l}\text { Changes in the socio-economic systems due to new employment } \\
\text { opportunities, inflation, income differentiation }\end{array}$ \\
\hline All phases and activities & $\begin{array}{l}\text { Changes in socio-cultural systems, such as social structure, practices and } \\
\text { beliefs and value systems }\end{array}$ \\
\hline
\end{tabular}

Compiled using information from E\&P Forum/UNEP [11] and World Bank Group [12].

eSome of the reported impacts on the marine biological environment include the disruption of behaviour of marine mammals due to noise, the effect of light on the diel vertical migration of phytoplankton, and damage to benthic organisms from the setting of anchors on the seabed [10].

DOI: $10.36959 / 742 / 238$

Copyright: (C) 2021 Bynoe P, et al. This is an open-access article distributed under the terms of the Creative Commons Attribution License, which permits unrestricted use, distribution, and reproduction in any medium, provided the original author and source are credited. 